\title{
The Woman in Labour: A Twelfth-Century Navarrese Relief from the Church of San Martin de Tours, Artáiz
}

\section{Dilshat Harman}

Independent scholar, Russia, dilshat.harman@gmail.com

\section{Abstract}

Among other corbels on the façade of the Church of San Martin de Tours in Artáiz (Navarra - Spain, twelfth century), an interesting relief depicts a woman while giving birth. Childbirth in medieval art is a fascinating subject, as it can portray the differences between medieval and contemporary attitudes regarding sex and gender. How is childbirth depicted? Why is it depicted at all? This essay will analyze the meaning and scope of the childbirth relief within the context of early Medieval culture and recent research in Romanesque marginal art.

Keywords: San Martin de Artáiz; Spain; Romanesque; portal; twelfth century; gender; childbirth. 


\title{
The Woman in Labour: A Twelfth-Century Navarrese Relief from the Church of San Martin de Tours, Artáiz
}

\author{
Dilshat Harman \\ Independent scholar, Russia
}

\section{Artáiz (Spain) - history and description}

Artáiz is a small village (with less than 50 inhabitants today) located about 10 kilometres from Camino Aragonés. Almost nothing is known about the early history of the Church of San Martin de Tours in Artáiz, Navarra (Fig.1). ${ }^{1}$ There is no document to attest its construction or later architectural developments. The church may have been built as a result of the Amoravids' presence in the area, as Artáiz was part of their landed property. Stylistic evidence shows that San Martin must have been built in the 1140s - 1150s and its sculpture was not crafted by local masters, but rather by Pamplonese craftsmen. ${ }^{2}$

\footnotetext{
${ }^{1}$ Martín Duque: "El origen fundacional de la iglesia es dudoso. No parece que sea una posesión del monasterio de Roncesvalles, ni del de Leire, que son los cenobios más extendidos por el reino de Navarra en estas fechas. Podemos pensar que fuera una iglesia cabeza de un señorío teniendo en cuenta que cercanas a la obra religiosa se conservan edificaciones civiles de época gótica. Como confirmación del carácter señorial de Artáiz diremos que figura en el Libro del Rediezmo de 1268 dentro del valle de Unciti y con la grafía de Artaytz" ("We are uncertain of the foundational origins of this church. It does not seem to have belonged to the Roncesvalles or Leire monasteries, which were the largest in the Navarra kingdom at this time. It may have been the main church of the manor, considering that there are several lay Gothic buildings in its close vicinity. In order to confirm the manorial character of Artáiz we can add, that it appears in the "Libro del Rediezmo" of 1268 as situated in the valley of Unciti (it is spelled Artaytz there"). See: Esperanza Aragonés Estella, La imagen del mal en el románico navarro [The Image of Evil in Navarrese Romanesque Art] (Gobierno de Navarra, 1996), 104.

2 J.E.Uranga, "La Iglesia Parroquial de Artáiz" [The Parochial Church of Artáiz] Pirineos 59-66 (1961-62):139-144.
} 


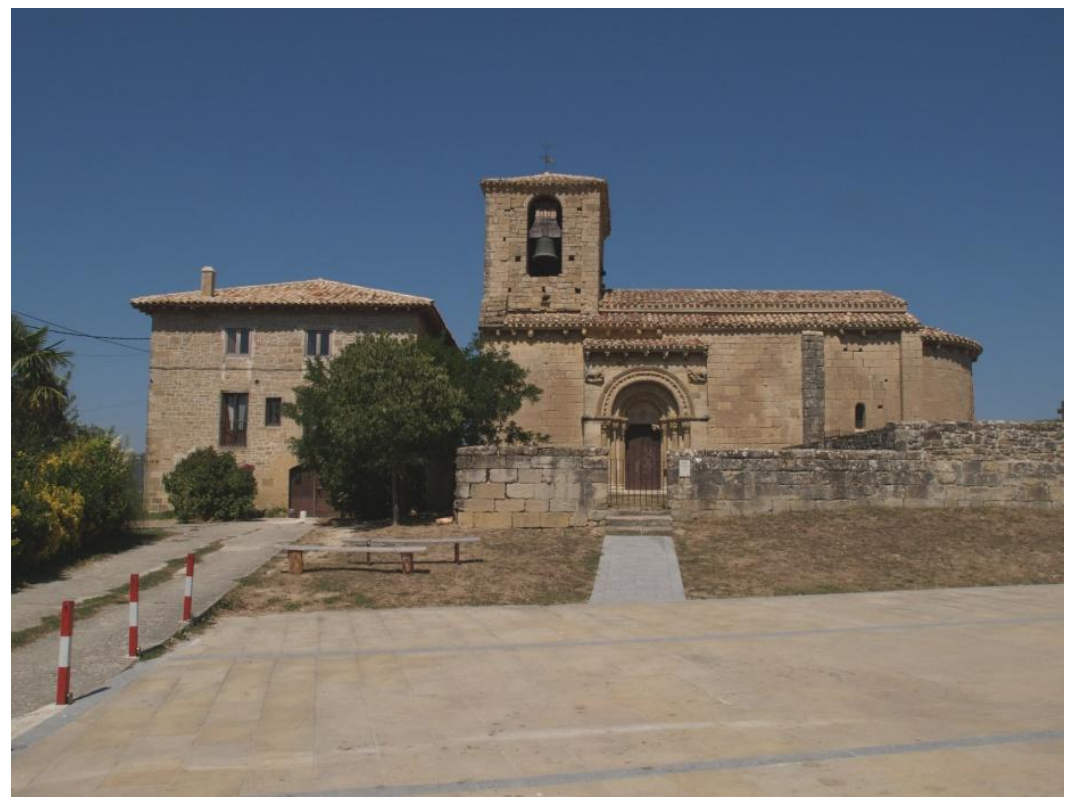

Fig. 1. San Martin de Artáiz. General view (photo: Antonio García Omedes)

Because the famous sites of Olorón, Jaca, Pamplona, and Puente de la Reina are located relatively close to Artáiz, they must have influenced the architecture and sculpture of San Martin. However, one cannot compare famous pilgrimage sites with a modest village church. San Martin was never a pilgrimage site, nor was it in possession of any important relics. It seems that some pilgrims have visited Artáiz on their way to or from Santiago de Compostela (especially the ones who previously stopped by the shrine of Saint Martin de Tours in France). ${ }^{3}$ Therefore, this essay will focus primarily on the local inhabitants as the audience of the relief of San Martin that is to be discussed.

${ }^{3}$ Artáiz is not on the pilgrimage road to Santiago de Compostela -- it is situated only 10 $\mathrm{km}$ from Monreal which is on the Camino Aragones. Unfortunately, there is no evidence of any pilgrims coming there in the twelfth-thirteenth centuries, but given that Saint Martin of Tours, the saint patron of the church, was largely popular, we can at least suppose that some pilgrims could deviate from their route to visit his sanctuary. The main sanctuary of the saint was (and still is) in Tours (France), the town which is situated on one of the pilgrim roads to Santiago de Compostela. 
The sculpted portal is located on the southern side of the building (Fig. 2) and it is rather complex for a village church (comparing it to the portals of similar villages such as Eresue or Vesolla, in close vicinity of Artáiz, they do not hold as many carvings and reliefs). The portal is supported by inhabited capitals which support decorated archivolts. The centre of the tympanum holds the Chrismon flanked by flowers and supported by two corbels. Two lions are on the spandrels flanking the portal, and on top of them are metopes and corbels with both religious and profane scenes. ${ }^{4}$ Several profane corbels can also be seen beneath the roof.

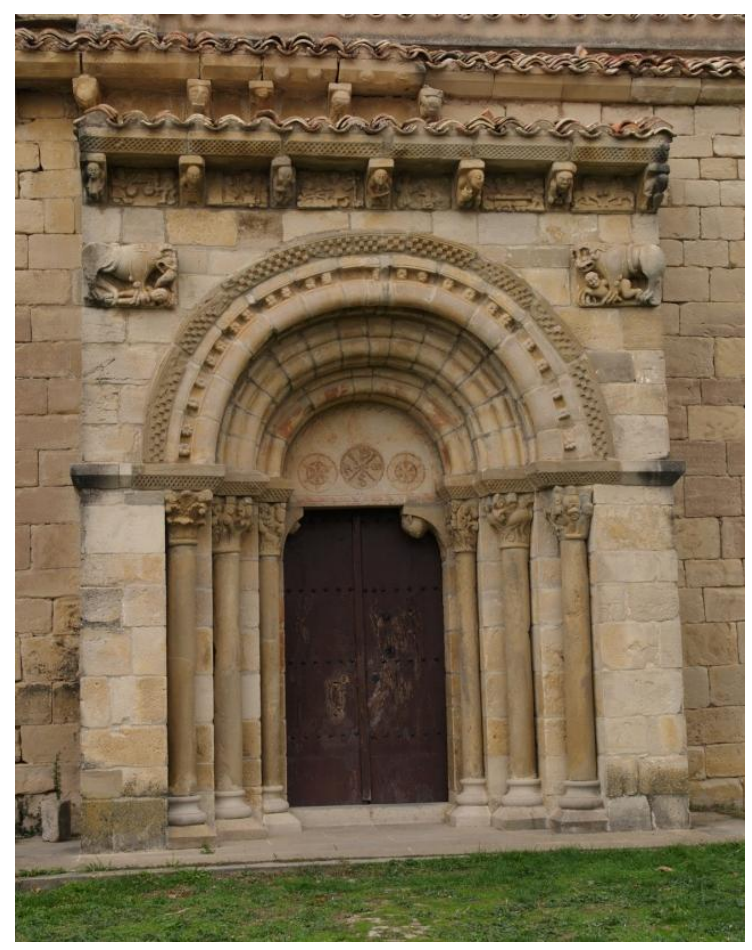

Fig. 2. San Martin de Artáiz. The portal. (photo: Antonio García Omedes)

${ }^{4}$ Decorated metopes are rather rare in Romanesque art. Other examples in Spain include Santa Maria de Carrión, San Quirce in Burgos, and Santa María de Narzana. 
The lower part of the portal is also decorated with capitals holding ornamental motifs, human figures in scrolls, and a strange three-faced figure (the same figure being repeated in one of the corbels on the top register $^{5}$ ). A row of carved corbels is also seen under the roof which is only discontinued in a segment which was renovated in the sixteenth century.

Apart from the sculpted portal, several reliefs also appear inside the church, notably two schematic capitals, depicting the Annunciation. Murals picturing scenes from the Apocalypse were added in the thirteenth century in the altar, which are today kept at the Museo de Navarra.

The discussion should begin with the Chrismon from the tympanum. The monogram showing the abbreviation of the name of Christ almost disappeared from European art after the sixth century, but it occasionally appeared in Spain between the eleventh and the thirteenth centuries. ${ }^{6}$ It became especially popular in Aragon and Navarra, as these kingdoms were actively participating in the Reconquista. Ruth Bartal writes:

Since the symbol had imperial and military as well as religious connotations, it perfectly suited the ideology of the Spanish kings, as an emblem symbolizing their double task, as warriors of the Reconquista, as standing at the head of their armies, as liberators of Spain from the heretics and as defenders of the Catholic faith and its tenets. The political and religious situation of the early Christian period continued to exist in Spain much longer than in any other European country. ${ }^{7}$

In most cases, the Chrismon appears in churches associated with Spanish kings and the Reconquista wars. It is frequently depicted in castles and on kings' tombs and should be understood as part of the Reconquista's conception as a holy war. ${ }^{8}$ Spanish and Bearnese

\footnotetext{
${ }^{5}$ On this figure, see: C.S.Vázquez, "Ab Austro Deus, El Trifonte Barbado de Artáiz, un intento de interpretación," [Ab Austro Deus, the Three-faced Bearded Man from Artáiz. an Interpretation Attempt] Príncipe de Viana 58, no. 212 (1997): 483 - 495.

${ }^{6}$ See R. Bartal, "The Survival of Early Christian Symbols in Twelfth Century Spain," Principe de Viana 48, no.181 (1987): 299 - 315.

${ }^{7}$ Ibidem, 311.

${ }^{8}$ Ibidem, 300.
} 
variations add the letter $\mathrm{S}$ to the early Christian version, while it reads Jesus Hominum Salvator/ Sol Invictus/ Christi Passio Salus.

The Chrismon was represented either as an isolated symbol or part of a heraldic or figurative composition. We see it between two angels in Huesca and Sant Engrace, and between two lions in Jaca. ${ }^{9}$ In Jaca, San Martin de Artáiz, Zaragoza, and Santa Cruz de la Seros it is accompanied by flowers. ${ }^{10}$

The Chrismon composition in Artáiz resembles the composition on the portal in Jaca (located 100 kilometres away). Both versions present the Chrismon between two lions, one of them dreadful, the other merciful. Several inscriptions were preserved in the portal of Jaca, thus helping understand the programme of the churches in both Artáiz and Jaca. ${ }^{11}$ The two lions symbolize two aspects of Christ - He either can grant eternal life or lead one to perish in hell for eternity. Thus, Susan Caldwell highlights the connection visible here with the theme of the

\footnotetext{
${ }^{9}$ Francisco de Asís García García sees in the Chrismon of Jaca the aniconic solution to the problem of the representation of the Trinity. see: F. de Asís García García, "La portada occidental de la catedral de Jaca y la cuestión de las imágenes," [The Western Portal of the Jaca Cathedral and the Question of its Imagery] Anales de Historia del Arte vol. extraordinario (2010): 69 - 89.

10 These are daisies-pearls (margaritas), symbols of THE Eucharist, as Venantius Fortunatus wrote: Quam bene iuncta decent, sacrati ut corporis agni / margaritum ingens aurea dona ferant! / cedant chrysolitis Salomonia vasa metallis: / ista placere magis ars facit atque fides. Carm III 201 - 4 (MGH AA IV 71).

11 The following can be read in the lower register: "VIVERE SI QVERIS QVI MORTIS LEGE TENERIS, HVC SVPLICANDO VENI RENVENS FOMENTA VENENI, COR VICIIS MVNDA, PEREAS NE MORTE SECVNDA" (oh you, subject to the laws of death, if you wish to live, come here with prayer, and reject damaging pleasures. Free your heart from sin, if you do not want to die the second death). Inscription over the lion to the left of the viewer: "PARCERE STERNENTI LEO SCIT XTVSQVE PETENTI" (The lion knows how to spare those who fall, and Christ knows how to spare those who seek His mercy). Surrounding the mandorla: "HAC IN SCVLPTVRA. LECTOR SIC NOSCERE CVRA: P. PATER. A GENITVS. DVPLEX EST SPS ALMVS: HI TRES IVRE QVUIDEM DOMINVS SVNT VNVS ET IDEM" (Oh reader, you should understand this sculpture this way: P stays for Father, A for the Son and X for the Holy Spirit. These three, each in His own right, are truly one and the same). The last inscription located over the lion to the left of the viewer: "IMPERIVM MORTIS CONCVLCANS LEO FORTIS" (The powerful lion triumphs over the empire of death).
} 
Last Judgement ${ }^{12}$ (thus the lions resonate with the Weighing of Souls on one of the metopes).

The corbels may be divided in two groups. The first one, including four corbels from left to right, is united by a general subject: the performance (Fig. 3). One can easily observe three musicians, playing the cythare, lute, or bagpipe and rebec, and a woman who is either a dancer or a jota singer. ${ }^{13}$ The second group consists of three corbels, but there is no general subject which binds them. One can see the woman in labour, a grinning man with a vessel which he holds on his genitals (Fig. 4), and a male figure with a shield with the sign of the cross depicted on it. A prostrated dragon is visible beneath the man with the shield. Researchers tried to identify this last figure, but they reached no unanimous agreement. The figure may thus represent either Saint George (although he is a rare figure in Navarrese art), the Archangel Michael (although the character has no visible wings), or simply an average Christian warrior struggling with evil (however, in such scenes, the dragon is not normally prostrated). As to the woman giving birth and the grinning man, there were no attempts to associate them with existing iconographic models.

The metopes are arranged between the corbels. Their reliefs are religious although, as with the last three corbels, there is no apparent general theme. The first metope represents the demon and Saint Michael with scales, weighing the souls of the deceased (Fig. 5), while the second one represents the Sacrifice of Isaac. The third metope is dedicated to the Harrowing of Hell (Fig. 6), as the fourth one shifts the attention from biblical and apocryphal scenes to a liturgical scene: two priests holding holy vessels during mass to mark the moment of transubstantiation. The fifth metope, between the woman in birth and the grinning man, shows the feast from the Parable of the Rich Man and Lazarus (Fig. 7). Lastly, the sixth one depicts two fighting riders - this type of fight between equals can frequently be seen in Navarrese churches $\left.{ }^{14}\right)$.

12 S. H. Caldwell, "Penance, Baptism, Apocalypse: The Easter context of Jaca Cathedral's west tympanum," Art History 3. no. 1 (1980): 27.

13 It can be compared with other similar female figures holding their arms akimbo in Aguera and Hormaza.

${ }^{14}$ See examples in D.O.Martinez, "La Lucha de Caballeros en el Románico [The Fight of Equestrians in Romanesque Art]" Revista digital de Iconografia Medieval VI, no. 12 


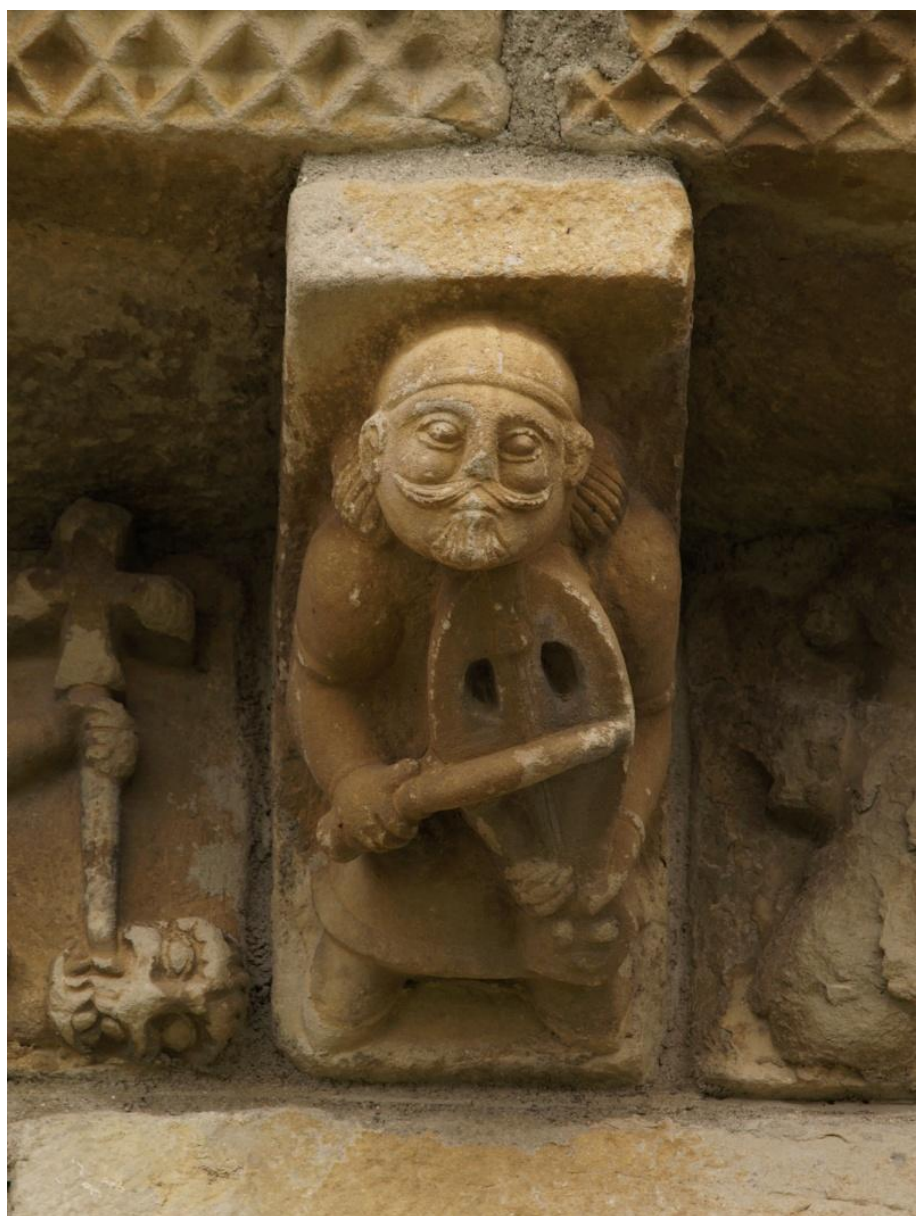

Fig. 3. San Martin de Artáiz. Corbel depicting a musician. (photo: Antonio García Omedes)

(2014): 29-41; M.R.Maldonado, "La Lucha Ecuestre en el Arte Románico de Aragón, Castilla, León y Navarra" [The Equestrian Fight in the Romanesque Art of Aragon, Castilla, Leon and Navarra] Cuadernos de Prehistoria y Arquieología de la Universidad Autónoma de Madrid 3 (1976): 61-90. 


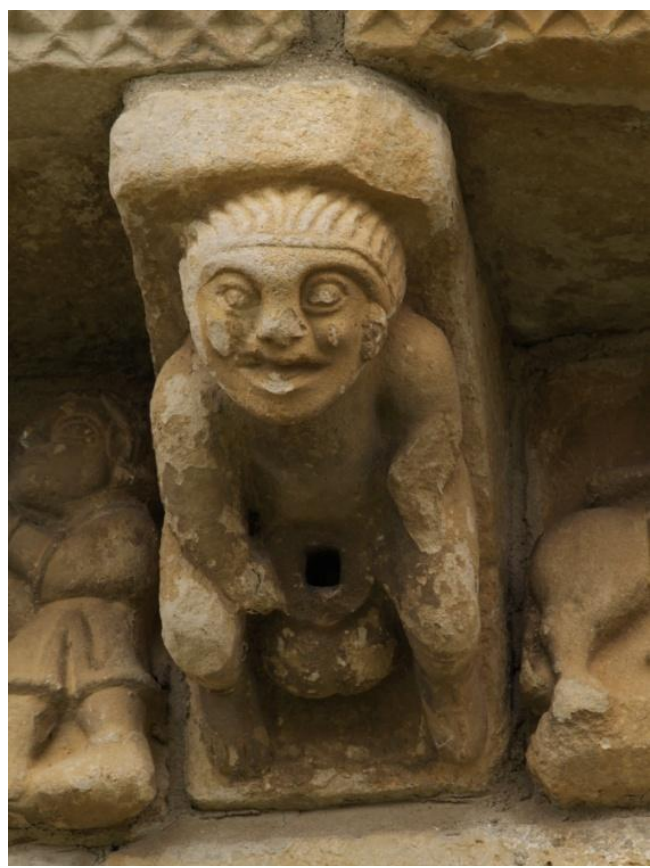

Fig. 4. San Martin de Artáiz. Corbel depicting a grinning man. (photo: Antonio García Omedes)

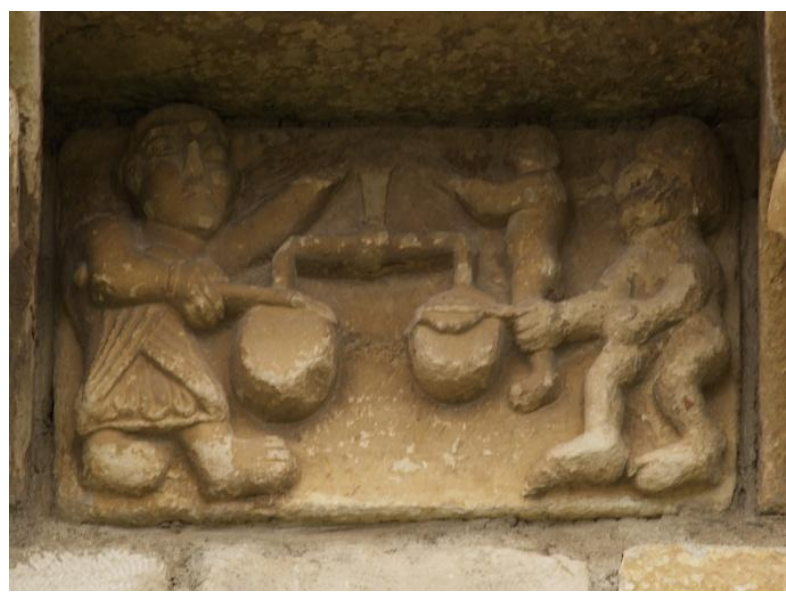

Fig. 5. San Martin de Artáiz. Metope representing the Weighing of Souls. (photo: Antonio García Omedes) 


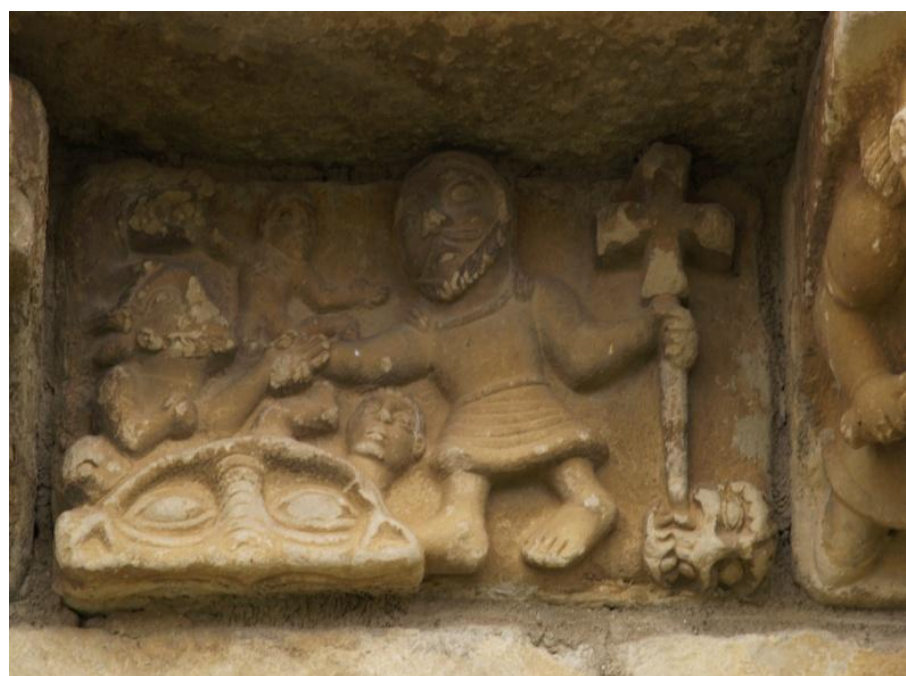

Fig. 6. San Martin de Artáiz. Metope representing the Descent into Hell. (photo: Antonio García Omedes)

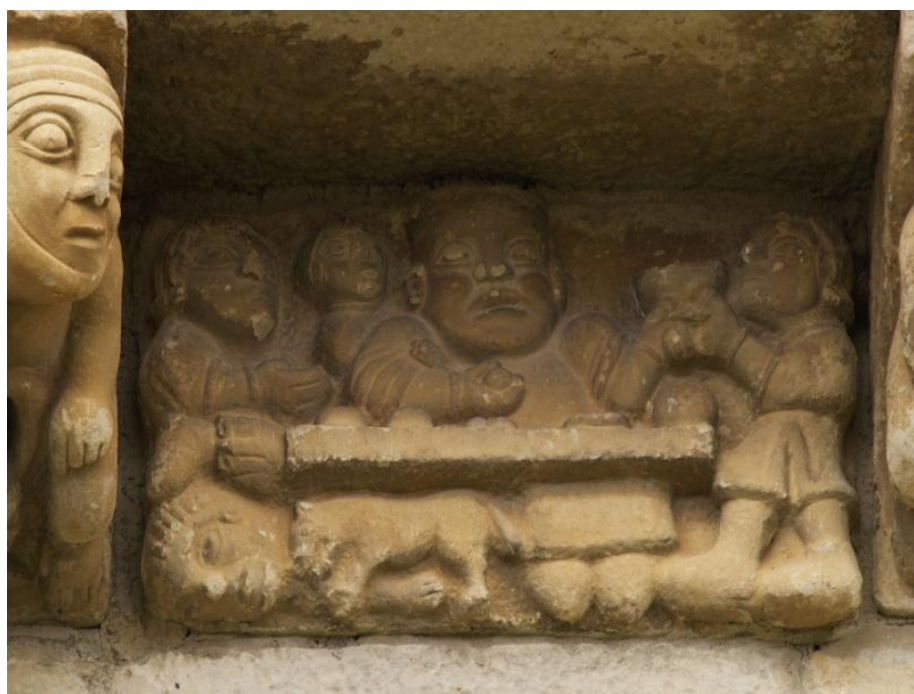

Fig. 7. San Martin de Artáiz. Metope representing the Parable of the Rich Man and Lazarus. (photo: Antonio García Omedes) 
It is difficult to find one sole theme for all the metopes. Mercedes Jover Hernando suggested that the metopes may be connected to the Passion and Easter. ${ }^{15}$ She highlights that the Sacrifice of Isaac typologically represents the Crucifixion and the Mass - Last Supper, although she does not discuss the meaning of the knights fighting on the last metope.

All the corbels in San Martin de Artáiz ${ }^{16}$ represent profane themes, just like many other corbels in Spanish and French churches, with musicians and exhibitionists being frequently represented. It should be mentioned that the corbels are much better positioned in relation to the viewer, while the metopes are in the shadow, thus making it difficult to examine them properly.

As already mentioned, the first four corbels (from left to right) display musicians and a singer/dancer with a small pendant reading the name GALA or GAIA. ${ }^{17}$ The fourth and last musician occupies an important position from a hierarchic point of view being placed above the Chrismon. The woman in labour is paired with the grinning man, while the warrior with the dragon remains unpaired.

In the words of Nurit Kenaan-Kedar,

the corbel series differ significantly from the official sculptural programs of facades, portals and other places of prominence. Such 'official art' uses a compositional model that is hierarchical and based on symmetrical contrasts such as high and low, good and evil, light and dark. Within the coherent context of a church portal for instance, individual figures and motifs have clear meanings that can be read and understood by the observer. ${ }^{18}$

Obviously, both schemes are visible on the portal in discussion: one with the lions on both sides of the Chrismon, and the other with corbels and metopes above the Chrismon.

15 M. J. Hernando, "Los ciclos de Pasión y Pascua en la escultura monumental románica en Navarra," [The Passion and Easter Cycles in Monumental Romanesque Sculpture in Navarra] Principe de Viana 48, no.180 (1987): 7-40.

16 The only exception here being the outermost corbels from the right side.

${ }^{17}$ Fernando Garcia Gil kindly turned my attention to this detail.

18 N. Kenaan-Kedar, "The Margins of Society in Marginal Romanesque Sculpture," Gesta 31, no. 1 (1992): 15. 
The corbel depicting the woman in labour will be described next, as she is seen in Fig. 8. She is wearing a two-part headdress (a toca, which covers both head and neck), the attribute of decent ${ }^{19}$ married women. She is sitting, her body naked (except for the toca), although her breasts are not visible. Her private organs are shown as a hole in her body, with the child appearing underneath it. Only the upper part of the infant's figure is visible, as his mouth is half-open, and his right hand holds on to a knife. Both figures are turning their hands to their left. The woman holds a vessel in her right hand. Her mouth is slightly open too, although her face is not deformed by pain and her hands are not close to her face in a gesture of pain.

The grinning man, the corbel "pair" of the woman in labour, is not more comprehensible. He is also sitting, like the woman in labour. He is not clothed, and the only way to identify his gender is through his hairstyle. A square hole appears in place of his genitals, under which either a large vessel or a scrotum ${ }^{20}$ is visible. His right hand holds this "vessel," while his left hand is broken off. It is similar to corbels of exhibitionists, frequently depicted in Spanish churches (which are sometimes arranged in pairs, as in El Olmo and San Pedro de Tejada), although this one is the only one that joyfully demonstrates the absence of virility by not representing it explicitly.

The man is connected to the woman in labour through the hole/vessel motif. Some Spanish researchers suggested that the man's vessel could be a urinal or a night-stool, ${ }^{21}$ although there is no evidence to back this hypothesis. Within this context, it must be noted that in the

\footnotetext{
${ }^{19}$ Compare with the toca on the head of Luxuria in Teza de Losa. The toca serves there as an aggravation, implying that the woman is guilty not only of lust, but also of adultery.

${ }^{20} \mathrm{On}$ his fascinating website dedicated to Romanesque churches in Spain, Antonio García Omedes suggested that the hole was intended to hold a metal rod, connecting the figure with the corbel and symbolizing the penis. So far I have not found the source of this suggestion. A similar figure with a cavity instead of a penis can be seen, for example, in Saint-Marcouf (France). See: http://www.arquivoltas.com/6Navarra/Artaiz04.htm,

21 Navarra: enciclopedia del románico en Navarra [Navarra: Encyclopedia of Romanesque Art in Navarra], ed. Miguel Ángel García Guinea, José María Pérez González and Javier Martínez de Aguirre Aldaz. Monasterio de Santa María la Real de Aguilar de Campóo (Fundación Santa María la Real, Centro de Estudios del Románico: 2008), 245; Esperanza Aragonés Estella, La imagen del mal en el románico navarro [The Image of Evil in Navarrese Romanesque Art] (Pamplona: Gobierno de Navarra, 1996), 49.
} 
corbels' uppermost row, two corbels depict an upturned vessel and, next to it, the phallus.

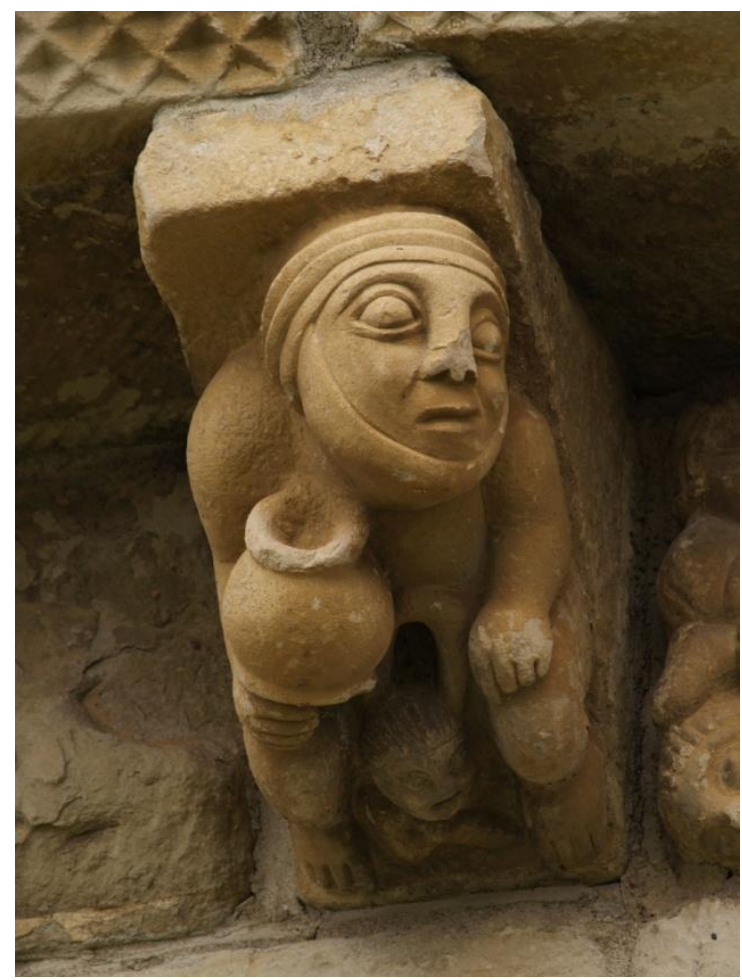

Fig. 8. San Martin de Artáiz. Corbel representing Woman in Labour. (photo: Antonio García Omedes)

\section{The medieval iconography of labour}

The Bible is ambiguous about labour. On the one hand, it is part of God's commandment: So God created man in his own image, in the image of God he created him; male and female he created them. And God blessed them. And God said to them, "Be fruitful and multiply and fill the earth and subdue it" (Genesis, 1, 27-28).

On the other hand, it represents the punishment of Eve and her daughters for the original sin: I will surely multiply your pain in childbearing; in pain you shall bring forth children (Genesis 3, 16). 
The Virgin Mary is a second Eve (this parallel is present as early as the second century ${ }^{22}$ ), redeeming her sin, as her childbearing is completely painless. Augustine, addressing the Virgin Mary, says: "In conceiving thou wast all pure, in giving birth thou wast without pain."23 Furthermore, Thomas Aquinas brought scientific arguments for the painless birth of the Virgin Mary:

The pains of childbirth are caused by the infant opening the passage from the womb. Now it has been said above (Q28, A2, Replies to Objections), that Christ came forth from the closed womb of His Mother, and, consequently, without opening the passage. Consequently there was no pain in that birth, as neither was there any corruption; on the contrary, there was much joy therein for that God-Man "was born into the world," according to Isaiah 35:1,2: "Like the lily, it shall bud forth and blossom, and shall rejoice with joy and praise." 24

Theologians of the twelfth and thirteenth centuries (Rupert of Deutz, Albert the Great, Anthony of Padua) already speculated that the pain Mary did not feel in birth returned at the bottom of the Cross, where she experienced it "with interest." 25 Nevertheless, no one could claim that Mary gave birth as an ordinary woman.

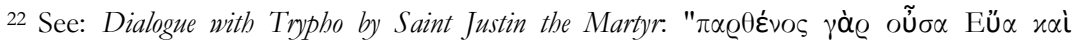

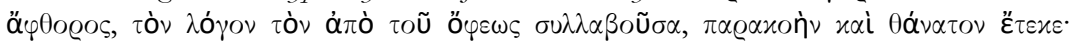

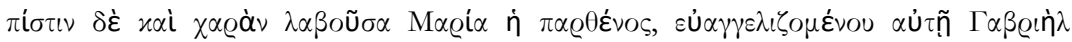

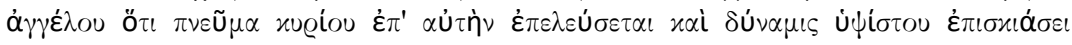

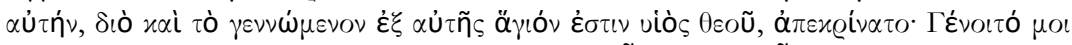

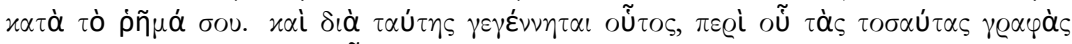

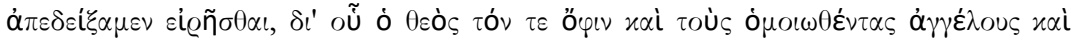

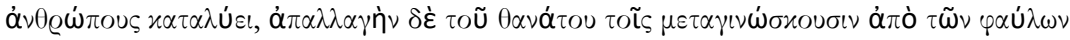

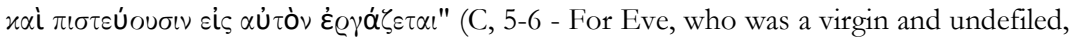
having conceived the word of the serpent, brought forth disobedience and death. But the Virgin Mary received faith and joy, when the angel Gabriel announced the good tidings to her that the Spirit of the Lord would come upon her, and the power of the Highest would overshadow her: wherefore also the Holy Thing begotten of her is the Son of God; and she replied, 'Be it unto me according to thy word.' And by her has He been born, to whom we have proved so many Scriptures refer, and by whom God destroys both the serpent and those angels and men who are like him; but works deliverance from death to those who repent of their wickedness and believe upon Him (http://www.earlychristianwritings.com/text/justinmartyr-dialoguetrypho.html)).

23 St.Thomas Aquinas. Summa Theologica, Third Part (Woodstock, Ontario: Devoted Publishing, 2018), 172.

${ }^{24}$ Ibidem, 172.

25 A. Neff, "The Pain of Compassio: Mary's Labor at the Foot of the Cross," The Art Bulletin 80, no. 2 (1998): 254 - 273. 
The childbirth scene par excellence in medieval art is, of course, the Nativity. However, the Nativity depicts the scene unfolding after the actual labour, not the process itself. Furthermore, it is a miraculous scene, where the mother remains virgin. ${ }^{26}$ Other popular medieval depictions of women in labour include Anna and Elisabeth (here, the iconography resembles that of the Nativity), Rebecca and Thamar of the Old Testament, who are sometimes shown during labour, ${ }^{27}$ and ordinary women represented in miracle scenes. ${ }^{28}$ The decorum is relevant in all these scenes. There can be signs of pain (such as hands near the face), although women are not represented naked. An interesting and unique image of Mother Church giving birth to its children by mouth appears in the middle of the twelfth century in the famous mystical book Scivias by Hildegard von Bingen. ${ }^{29}$ This image seems to not have been used (at least to my knowledge) anywhere else.

These are the usual medieval depictions of childbirth. Nevertheless, another representation of childbirth was developed in Spanish 30 Romanesque "marginal" sculpture: the representation of a woman far into her pregnancy or in the process of birth, with contorted body, sometimes with the head of the child already visible between her legs. Gómez Gómez highlights five examples of this iconographic type: in

\footnotetext{
${ }^{26}$ Gospel of pseudo Matthew: "Zelomi said to Mary: Allow me to touch thee. And when she had permitted her to make an examination, the midwife cried out with a loud voice, and said: Lord, Lord Almighty, mercy on us! It has never been heard or thought of, that any one should have her breasts full of milk, and that the birth of a son should show his mother to be a virgin. But there has been no spilling of blood in his birth, no pain in bringing him forth. A virgin has conceived, a virgin has brought forth, and a virgin she remains." See: http://gnosis.org/library/psudomat.htm..

27 Cotton Ms Claudius B.IV - eleventh century, Thamar. Later examples include Thamar from Egerton Genesis and Rebecca from the Queen Mary Psalter.

28 See, for example, Jewish and adulterous women from the Cantigas de Santa Maria in the Biblioteca de El Escorial (images are shown in Agustin Gómez Gómez, "La iconografía del parto en el arte románico-hispano" [The Iconography of labour in Spanish Romanesque Art] Principe de Viana 213 (1998), fig. 2 and 3, the pregnant woman from the portal of the Fidenza Cathedral (this example does not represent childbirth, but an ordinary pregnant woman, which is rare in early medieval art).

29 See the Rupertsberger Scivias-Kodex (ca.1200, Hessische Landesbibliothek, Wiesbaden, Hs.2), fol. 51r.

${ }^{30}$ Two examples outside of Spain are the followings: the corbel in Sankt Leonhard in Tholbat, Germany and a Victorian "birthing" corbel at Romsey Abbey (Great Britain), which is thought to be a replacement for the lost Romanesque corbel of the same design.
} 
the churches of Artáiz, Cervatos (Cantabria), Corullón (León), Revilla de Santullán (Palencia), and Villanueva de la Nía (Cantabria) ${ }^{31}$ (Fig. 9). I had found several other examples: in the churches of San Pedro de Tejada (Fig. 10) (where the woman is represented as half-feline), Santa Marta del Serro, and Vera Cruz at Zamarramala (the women in these last two churches are in their last trimesters of pregnancy, ready to give birth). Another fascinating example dates to the thirteenth century: it is a representation of the she-devil in Cifuentes, giving birth to a child wearing a crown and sceptre (Fig. 11). Its representation is especially important as, apart from the representation in Artáiz, it is the only known depiction of a parturient female where the child has attributes of its own.

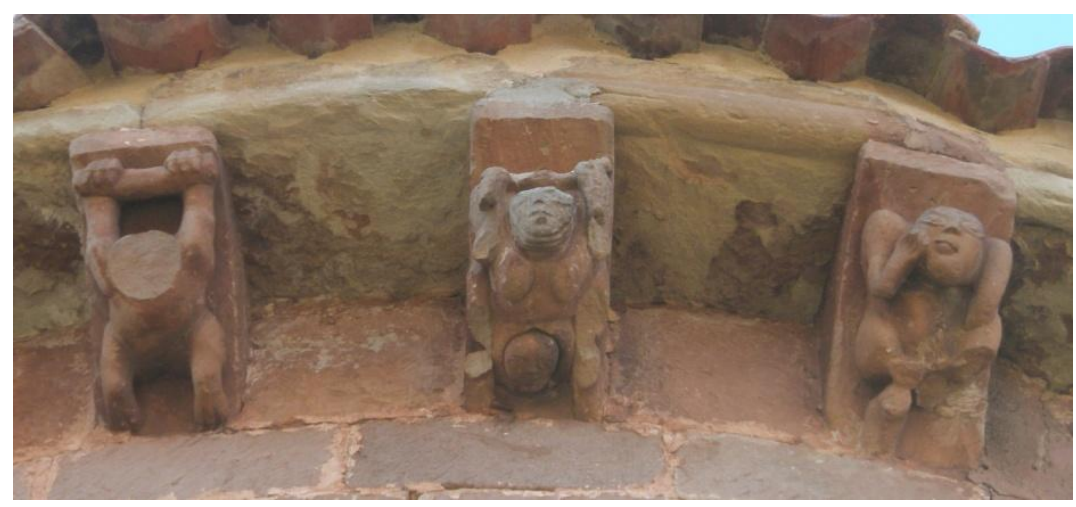

Fig. 9. San Juan Bautista (Villanueva de la Nia, Cantabria).

Corbel with Woman in Labour. Twelfth century (photo: Fernando Garcia Gil)

The meaning of Romanesque parturient women is obscure. As a rule they decorate corbels and are located close to nude figures of both sexes exposing their genitals, acrobats, contorted bodies of sinners, and copulating pairs. ${ }^{32}$ Their presence could have an apotropaic function and could be explained as an admonition against sin and the superstitious beliefs of the time's rural Spain; nevertheless, they could also be a manifestation of the carnival nature of art. ${ }^{33}$ Whichever the

\footnotetext{
31 Gómez Gómez, "La iconografía del parto en el arte románico-hispano," 94-97.

32 Ibidem, 93.

${ }_{33}$ Gómez Gómez explains that they belong to the same semantic field as other corbel figures in negative context.
} 
case, parturient women are represented closely to sinners and demons, as their postures suggest that childbirth was understood as something entirely carnal, and even bestial. ${ }^{34}$

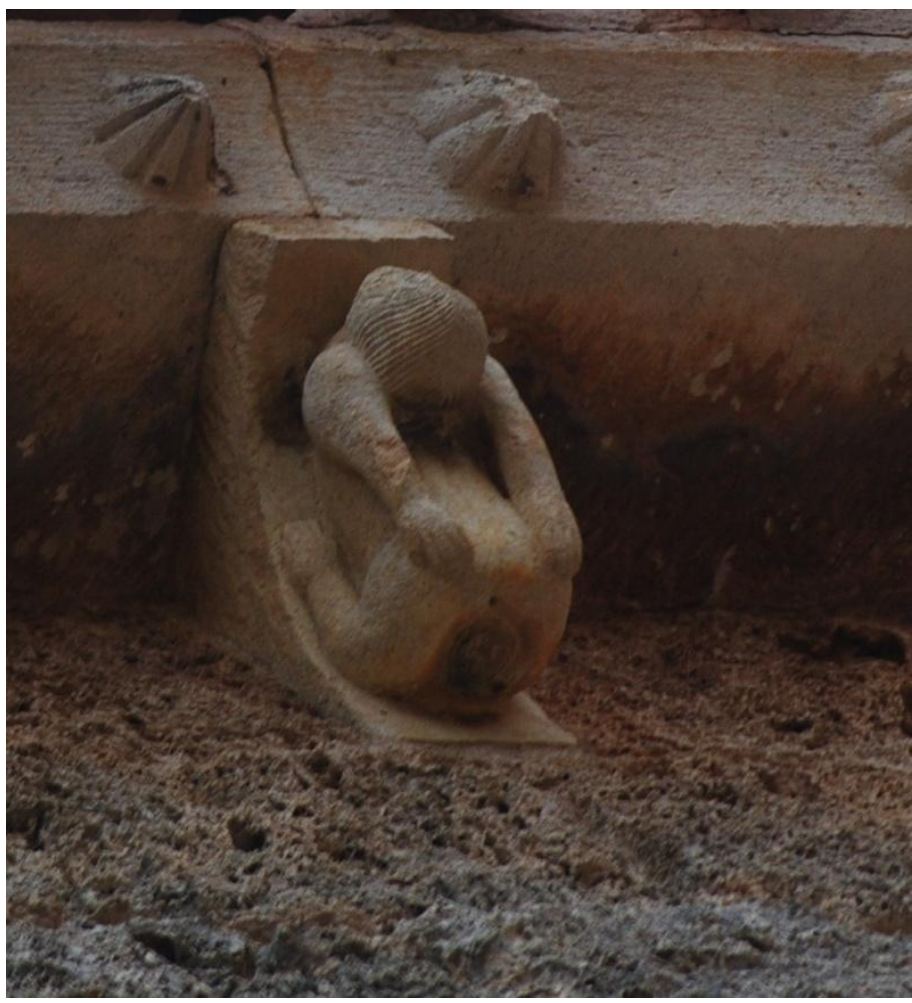

Fig. 10. San Pedro de Tejada. Corbel with Woman in Labour. Twelfth century (photo: Fernando Garcia Gil)

${ }^{34}$ See especially the corbel in San Pedro de Tejada. 


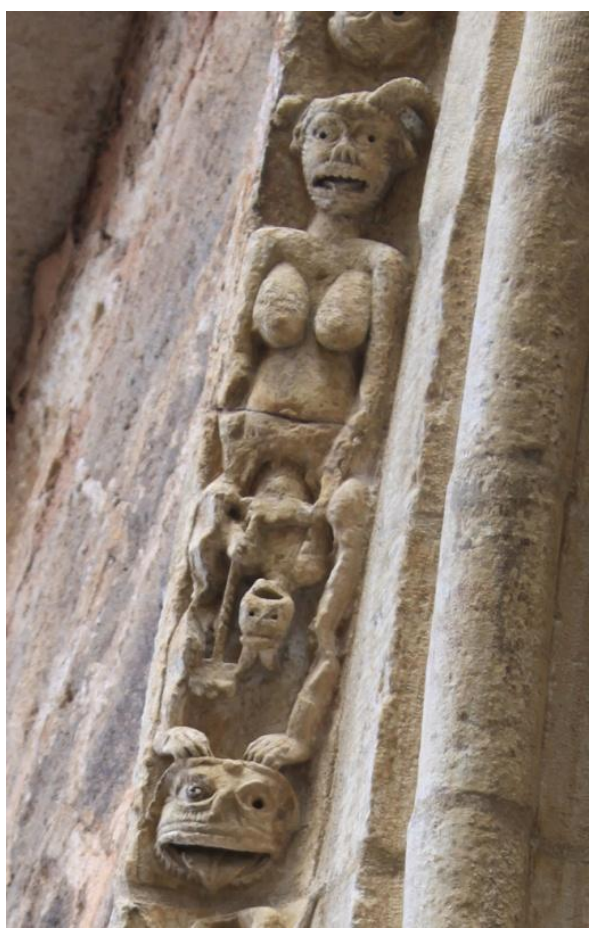

Fig. 11. El Salvador (Cifuentes). Portal fragment with the She-Devil giving birth. Thirteenth century (photo: Ingeborg Brauneis Toledano)

\section{Gender issues. Romanesque women in labour}

No attention has been given yet to the connection between pregnant and labouring women and sheela-na-gigs. In her detailed research on sheela-na-gigs, ${ }^{35}$ Barbara Freitag suggested that they were connected with birth and death, in particular. She argues that they were used by women as talismans to help them in labour and several aspects of their representation indicate different phases of labour:

The most obvious clue is the seemingly grotesque-looking lower abdomen of the sculpture. The cavernous ovalshaped vulva, pointed to or held open by her hands, often shown as swollen or sagging, mostly pointing downwards,

35 Barbara Freitag, Sheela-na-gigs: Unravelling an Enigma (London: Routledge, 2004). 
and in some cases so big as to reach the ground, finds a perfect explanation: it expresses the physical state pregnant women craved and worked for. It shows the desirable degree of dilation of the cervix immediately before, during or after childbirth. Touching a vulva so indicative of parturition surely must have filled pregnant women with the hope and energy necessary to push on with their own business. Better still if they knew the right magic formula to accompany the action. It is small wonder then to read that the genital area of those Sheelas who were placed within reach was found to have been 'rubbed.'36

While working on her book, Dr. Freitag was unaware of the existence of the women in labour on Spanish corbels. I presented them to her in our correspondence and she then realized that they support her theory. Nevertheless, I believe that birthing women in Romanesque art could not function as talismans. They are normally located so up high that it is impossible to rub or otherwise touch them, and the sculptural context speaks in defence of the rather negative message connected to childbirth. Their purpose is seemingly not to help women, but, rather, to preach to them.

I argue that these representations are most probably the creations of men, showing men's medieval conception of childbirth. It is the appropriation of the female experience of pain and suffering.

Anonymous medieval women in labour are indeed connected with exhibitionist women because in both cases the attention of the viewer is directed to their genitals - an otherwise unrepresented body part. While there is no indication of the function of exhibitionist figures, there is one certain difference: regardless of their neutral facial expressions, the representations of labouring women (and the representation of their genitals) are associated with pain. This connects them to the images of Luxuria in Romanesque art, in which women are punished for their sexual intemperance in a particular way: frogs and snakes suck their genitals and breasts. ${ }^{37}$

\footnotetext{
${ }^{36}$ Eadem, 89.

${ }^{37}$ Examples of such representation are plenty. To cite only few Spanish examples, we can list the figures in the Girona Cathedral, Santa Maria la Real in Sanguesa, or Santa Maria in Tarragona. For a thorough analysis see Anthony Weir, James Jerman, Images of Lust: Sexual Carvings on Medieval Churches (London: Routledge, 1986).
} 


\section{Romanesque women in labour and carnival culture}

Labouring women may also be discussed from a Bakhtinian perspective, as manifestations of the "pregnant death." 38 Mikhail Bakhtin's ideas on carnival were also used for the better understanding of some artworks:

By relating Rabelais' images to other medieval creations representing the grotesque body, Bakhtin acquaints us with a system that gives us a better understanding of an enigmatic dimension in European culture: the series of strange illustrations in medieval manuscripts, on column capitals and in the paintings of Breughel and Bosch. ${ }^{39}$

Bakhtin's description of the popular comic body matches very well Romanesque corbels: the most frequent figures in corbels are vertiginous acrobats and grimacing faces.

A deeper and more subtle analysis would disclose in many traditional popular comic gestures and tricks a mimicking of childbirth such as we observed in the little Italian scene. Moreover, the great majority of these traditional gestures and tricks is based on the mimicking of the three main acts in the life of the grotesque body: sexual intercourse, death throes (in their comic presentation-hanging tongue, expressionless popping eyes, suffocation, death rattle), and the act of birth. Frequently these three acts are transformed or merged into each other insofar as their exterior symptoms and expressions coincide (spasms. tensions. popping eyes, sweat, convulsions of arms and legs). This is a peculiar mimicking of death-resurrection; the same body that tumbles into the grave rises again, incessantly moving

\footnotetext{
38 On the carnival nature of Romanesque corbels see M. Ángeles Menéndez Gutiérrez, Representaciones antropomorfas de carácter profano en el románico bispano: La sexualidad en el contexto religioso de la Iglesia Anthropomorphous [Representation of Profane Character in Spanish Romanesque Art. Sexuality in the Religious Context of the Church] (Tesis por la Universidad Nacional de Educación a Distancia (UNED), PhD Dissertation,1995).

${ }^{39}$ Gabor Klaniczay, "The Carnival Spirit: Bakhtin's Theory on the Culture of Popular Laughter," in The Uses of Supernatural Power: The Transformation of Popular Religion in Medieval and Early-Modern Europe, ed. Karen Margolis (Princeton: Polity Press, 1990), 18.
} 
from the lower to the upper level (the usual trick of the clown simulating death and revival). ${ }^{40}$

The danger of this approach stands in entirely placing childbirth imagery in the field of popular culture, thus disconnecting them from the high and literate religious semantic field. I think that the Artáiz image successfully unites these two fields, and clearly shows that there is no such disconnection.

\section{Interpretations of the Artáiz woman}

Ichnographically and stylistically, the woman from Artáiz belongs to the group of anonymous parturient women. Still, there are some peculiarities which make her different:

1) Her new-born holds a knife in its hand

2) She holds a vessel herself

3) Her body and face are not disfigured by pain

4) She is represented on the façade

For these reasons, Gómez Gómez proposed an original interpretation of this mother-child figure. He sees in it an illustration of the words of Apostle James: "Then desire when it has conceived gives birth to sin, and sin when it is fully grown brings forth death." 41

This proposition fits well into the general subject of the portal, determined by the Chrismon and lions. The opposition between $\sin /$ death and righteousness/life is visible. Still, this proposition is not backed by solid arguments and there are no iconographical parallels to it. Moreover, this fragment from the Apostle James has never been illustrated in art. We do not even know of other depictions of death in Romanesque art - the only known example is the relief from SaintGeorges in Boscherville (Normandy), where the figure holds a knife and phylactery with the inscription EGO MORS HOMINEM JUGULO CORRIPIO. It is indeed interesting that both this figure and the child from Artáiz are holding knives, but their similarity ends here. ${ }^{42}$

\footnotetext{
40 Mikhail Bakhtin, Rabelais and His World (Indiana University Press, 1984), 353-354.

${ }^{41}$ James 1:15.

${ }^{42}$ Barbara Freitag, in a private letter to me, suggested that the knife is consistent in a birth-giving context, i.e. as a cutting instrument for the umbilical cord. She also noticed that there was at least one sheela-na-gig with some kind of knife at her hand - an Egremont sheela, which is now lost.
} 
Reviewing the sequence of metopes and corbels once again, we notice that the woman is the only corbel character who is not looking directly at the viewer. Instead, her head is turned to the left. This feature alone can connect her with the scene on the adjacent metope, or at least, with the grinning man on the next corbel. The vessel which the woman holds in her right hand stands in favour of the connection with the metope. While it can be seen as her own attribute, it can also belong to the scene of the feast. The fact that men and women showing their private parts occur frequently on adjoining corbels in Spanish Romanesque churches ${ }^{43}$ is proof for the connection of the woman in labour with the grinning man. It is true that these figures are apparent exhibitionists, and while the imagery bears a more complex message, the likeness is nevertheless present (the woman demonstrates her private parts while producing a child and the man holds a vessel in a manner that alludes to his phallus).

The woman in labour is gazing towards the scene on her left, depicting the Parable of the Rich Man and Lazarus, ${ }^{44}$ a popular motif in Spanish Romanesque sculpture. ${ }^{45} \mathrm{~A}$ man is lying beneath the table while two dogs are approaching, thus this scene undoubtedly represents the Parable: the figures underneath the table are Lazarus and dogs who "came and licked his sores" (Luke 16:21). The scene of the banquet was usually accompanied by two death and afterlife scenes. In the worldly life, the rich man was the happy one, while in eternal life the lucky one was Lazarus. As Charles F. Altman points out: "By far the most common location for the Dives and Lazarus parable... is the area directly adjacent to or above the church entrance: the tympanum, in a series of porch capitals, or in a sequence of reliefs." 46

\footnotetext{
${ }^{43}$ See, for example, El Olmo or San Pedro de Tejada.

${ }^{44}$ Luke 16:19-31.

45 Two protogothic portals in San Vicente (Avila), a capital with two deaths (of Lazarus and the rich man) in the Cathedral of Avila, a fragment of the fresco from San Clemente de Taüll with Lazarus awaiting at the door, the fresco and capital at San Martin de Mondońedo, the capital at San Cugat del Vallés, the capital at Tudela Cathedral, the altar panel from La Seo.

${ }^{46}$ Ch. F. Altman, "The Medieval Marquee: Church Portal Sculpture as Publicity," The Journal of Popular Culture.14, no. 1 (1980): 41. As Emile Male suggested, because beggars congregated at the church entrance to ask for charity, it was perfectly rational to depict the parable there in order to soothe and comfort them.
} 
Therefore, the location of the scene of the feast from the Parable in Artáiz is conventional. However, rather unconventionally, the parallel scene showing the two deaths is lacking. ${ }^{47}$ Still, this is not unique as the scenes representing death and afterlife also lack in San Matrin de Mondoñedo). Furthermore, the audience seems to have been well enough acquainted with the parable to have no need of the detailed narrative: this New Testament passage was read in churches all over Europe every year on the second Sunday after Pentecost. Afterwards, the priest read the homily and interpreted the parable, drawing inspiration from the rich exegetical sources, from Jerome and Augustine to Hugh of Saint-Victor. ${ }^{48}$ All the interpretations are preserved in Latin, but it is generally known that Latin texts were the basis for vernacular preaching in the eleventh and twelfth centuries. ${ }^{49}$

The parable was considered a good example for poor people. Therefore, Radulphus Ardens, in one of his sermons, explained that preaching about dives and pauper helps the poor and the sick to restrain from complaining or envying the rich, while setting the blame on themselves and understanding that their miserable condition is the result of their own sins. ${ }^{50}$ Symbolically, the Dives represented the Jews, Lazarus represented the Gentiles, hungry for knowledge, his sickness represented the sins of the Gentiles and the dogs licking Lazarus's wounds were the confessors, curing the sins with their counsel or the preachers erasing the sins through preaching. ${ }^{51}$

From the eleventh century onwards, the parable was often depicted not only in Spain, but throughout Europe, in stone, frescoes, miniatures. As a rule, they were not detailed depictions (detailed representations appear later, in the Gothic period). Because of the parable's popularity, it was enough to show the beginning of the story to the viewers in order for them to easily remember its entire story.

\footnotetext{
${ }^{47}$ For this reason, some scholars see an allegory of gluttony in this scene. See: Pedro Luis Huerta Huerta, "Las visiones infernales: pecados, pecadores y tormentos." [The Infernal Visions: Sins, Sinners and Torments], in Poder y seducción de la imagen románica (Aguilar de Campóo: Monasterio Santa María la Real, 2006), 99.

48 Altman, "The Medieval Marquee," 43.

${ }^{49}$ See Michel Zink, La Predication en langue romane avant 1300 (Paris: Honoré Champion, 1976), 85ff

50 Altman, "The Medieval Marquee," 43.

51 Ibidem, 43- 44.
} 
Mary Carruthers says that "medieval culture was fundamentally memorial" 52 and the

commonest model for human memory likened it to a tablet or a parchment page, upon which a person writes. Recollection was essentially a task of composition, literally bringing together matters found in the various places where they are stored to be reassembled in a new place. ... Far from being passive and thus (at least possibly) neutral, memory-making was regarded as active; it was even a craft with techniques and tools, all designed to make an ethical, useful product. ${ }^{53}$

Memory as a craft was associated not only with the ability of remembering, but with the active composition, imagination, inventiveness of the human mind. ${ }^{54}$

The role of visual images in this process was acknowledged by medieval theologians. For example, Hugh of Saint-Victor wrote about manuscripts' decorations and layouts as mnemonic devices. ${ }^{55}$ Similarly, in my opinion, the woman with the vessel and the child can be such a mnemonic cue and thus compensate for the lack of "death scenes" in the story of Dives and the pauper. It is an unusual and suggestive image, making the viewer remember the continuation of the parable: the menacing child with the knife, coming out of her womb is located on the same level as Lazarus is under the table. Moreover, his weapon is directed towards Lazarus. Thus, I believe this is not just an abstract death from Saint James' epistle, but a specific death, of a specific person.

But why was a moment of childbirth chosen for this purpose? The answer is possibly connected to the medieval understanding of leprosy. An apocryphal tradition notes that Lazarus the beggar was a leper. ${ }^{56}$

\footnotetext{
52 Mary Carruthers, The Book of Memory: A Study of Memory in Medieval Culture (Cambridge: Cambridge University Press, 2008), 9.

${ }^{53}$ Mary Carruthers and Jan M.Ziolkowski, "General Introduction," in The Medieval Craft of Memory: The Anthology of Texts and Pictures, eds. Mary Carruthers and Jan M.Ziolkowski (Philadelphia: University of Pennsylvania Press, 2003), 1-2.

54 Ibidem, 3.

55 Carruthers, "The Book of Memory", 10.

56 Peter Richards, The Medieval Leper and his Northern Heirs (Cambridge: Boydell \& Brewer, 2000), 8.
} 
Another tradition explained leprosy as a "punishment meted out for moral failing, especially for loose, wanton and lustful living." 57 A third tradition suggested that children's leprosy was the result of the sins of their parents, especially lust. In one of his sermons, Caesarius of Arles stated that leper children are born to the rustics, who do not refrain from sexual intercourse on feast days. ${ }^{58}$ It may be that the figure of the woman giving birth in the immediate proximity of Lazarus (and, furthermore, having the figure of her menacing child on the same level as Lazarus and facing him!) is making a statement about punishment for unbounded sexual relationships.

This representation will remain a mystery to the viewers who do not know the New Testament parable or the traditions connecting Lazarus with leprosy. However, this image will trigger recollections to those aware of its implications. Albertus Magnus (d. 1280) described the process of remembering as follows: one should concentrate "on what can distinguish one memory from another" 59 referring to places. Memories can look like real locations (a garden or a tower), but they are simply "fictive devices that the mind itself makes for remembering." 60 People normally remember distinctive things, and as the image of the woman in labour is a distinctive and rare image, it can play a significant role in reminding viewers about the sequel of the Dives's feast and the moral message of the story.

\section{Corbels and metopes: is there a connection?}

Before discussing a connection between corbels and metopes, one should highlight the general programme of corbel cycles? Nurit Kenaan-Kedar, in her research dedicated to the meaning of corbel sculpture, writes that every corbel is generally an autonomous unit with a double meaning: one for patrons, and another for ordinary viewers, as

\footnotetext{
57 Ibidem, 6.

58 "Denique quicumque (filii) leprosi sunt, non de sapientibus hominibus, qui et in aliis diebus et in festivitatibus castitatem custodiunt, sed maxime de rusticis, qiu se continere non sapiunt, nasci solent" (cited in Gómez Gómez, "La iconografía del parto en el arte románico-hispano”), 19.

${ }^{59}$ Carruthers and Ziolkowski, "General Introduction," 7.

${ }^{60}$ Ibidem, 8 .
} 
the sculptor acts as mediator between two. ${ }^{61}$ However, she does acknowledge the presence of a connection in certain cases: "In Cahors, for example, a corbel with a mocked, distorting mouth is turned towards a pair of lovers. Similarly, in Civray, the head of a woman with dice near her seems to be turned to look at the distorted male head beside her. In Rétaud a centaur bending a bow is located next to a deer with an arrow in its neck." 62

Nevertheless, it is more difficult to discuss the connection between the programmes of both metopes and corbels. Agustín Gómez Gómez is firmly arguing that, in Artáiz, the sacred metopes are opposed by profane corbels, although he acknowledges that the last corbel and last metope do not fit in this theory. ${ }^{33}$ However, there is at least one example of interwoven narratives of metopes and corbels. It is the cycle of the Genesis from the Church of San Quirce (Los Ausines). Los Ausines is rather far from Artáiz (about 230 kilometres, in Burgos), and San Quirce is not just a parish church, but a monastic one, consecrated in 1147 (approximately the same time as San Martin de Artáiz). Its portal is decorated with a series of alternating corbels and metopes, where corbels are decorated with scenes from the Genesis (beginning with the figure of the Creator and ending with God asking Cain about his brother Abel) and metopes with different motifs including animals, fighting men, a defecating figure and a naked pair. Metopes are mostly not connected with corbels by their themes, but towards the end of the cycle we can see that in two occasions, metopes continue and elaborate on the stories from the corbels. Thus, after the corbel showing Abel as he is offering God an animal from his flock, we see this flock on the metope; in the following corbel, which depicts the offer by Cain, we see

${ }^{61}$ N. Kenaan-Kedar, "The Margins of Society in Marginal Romanesque Sculpture." It may also be argued that the actual mediator is not the craftsman, but the commissioner of the programme. Still, the role of the sculptor should not be underestimated.

${ }^{62}$ Nurit Kenaan-Kedar, Marginal Sculpture in Medieval France: Towards the Deciphering of an Enigmatic Pictorial Language (Aldershot, Eng., and Brookfield, Vt.: Scolar Press, 1995), 36. 63 "Esta contraposición quedaría rota entre el último canecillo y metopa que presentan temas sacro y profano respectivamente, posiblemente por la imposibilidad de representar una lucha ecuestre en un canecillo" (This contraposition is not held between the last corbel and the last metope, which respectively represent the sacred and profane themes. Probably it happens due to the impossibility to represent the equestrian fight on the corbel). (Gómez Gómez, "La iconografía del parto en el arte románico-hispano," 94. 
on the next metope how Cain is ploughing the earth. This last metope even bears the inscription "KAIN AGRICOLA," so as to highlight that this is the Biblical character, not just a random ploughman.

Consequently, because of the example in San Quirce, one can highlight that, in principle, metopes and corbels can be united by the same narrative.

\section{Conclusion}

The meaning of the relief showing the woman in labour on the façade of the Church of San Martin de Artáiz can be explained by four approaches. The first one refers to the classical iconographical method, according to which one should find the textual origin for the image. This method is used by Agustín Gómez Gómez who argues that the words of the Apostle James are the basis for the depiction of the woman in labour.

The second approach uses Bakhtin's ideas regarding low and high cultures. Within the limits of this method, we consider the images on the corbels as "low" and "folk" and oppose them to the images on the metopes and to the Chrismon composition below. Analyzed through this approach, the parturient woman with the child and the vessel is paired with the grinning man with the vessel as they both personify sin and punishment.

Finally, the third approach also takes into account the Bakhtinian ideas, this time as developed by Michael Camille. The art historian argues that marginal images in stone or on manuscripts were manifestations of carnival culture. At the same time, he deprived them of the autonomy and creative potential, writing that they "work to reinstate the very models they oppose. For behind them, or literally often above them, is the shadow of the model they invert, either on the very same page ... or by reference to the widely known iconographic conventions they subvert." 64 Through this approach, the woman in labour can be connected to the adjacent scene from the Parable of the Rich Man and Lazarus and thus allows the interpretation of this figure in relation to the Gospel narrative.

${ }^{64}$ M. Camille, Image on the Edge: The Margins of Medieval Art (Cambridge, Mass.: Harvard University Press), 30. 
The fourth and last approach is to consider the parturient woman as a mnemonic device, helping the viewer remember the story of the Dives and the Pauper, an episode of which is depicted closely. The portal of San Martin de Artáiz can bring forth in the viewers' mind a system of associations, allowing them to think about how life and death are connected, like a map to salvation or a constant appeal to choose the right way, the way to life. 